\title{
Hydrogen autotrophy of Nocardia opaca strains is encoded by linear megaplasmids
}

\author{
Jutta Kalkus, Michael Reh and Hans G. Schlegel* \\ Institut für Mikrobiologie der Georg-August-Universität, Grisebachstrasse 8, D-3400 Göttingen, \\ Federal Republic of Germany
}

(Received 9 November 1989; revised 5 February 1990; accepted 26 February 1990)

\begin{abstract}
Several linear megaplasmids were detected in the facultatively lithoautotrophic Gram-positive bacterium Nocardia opaca. The wild-type strain MR11 contains, in addition to the cccDNA plasmids pHG31-a and pHG31-b, the linear plasmids pHG201 (270 kb), pHG202 (400 kb) and pHG203 (420 kb). The wild-type strain MR22 contains, in addition to the cccDNA plasmid pHG33, the linear plasmids pHG204 (180 kb), pHG205 (280 kb) and pHG206 $(510 \mathrm{~kb})$. After preparation of DNA from cells embedded in agarose, the linear plasmids were demonstrated by pulsed-field electrophoresis. By means of DNA probes for genes of soluble hydrogenase and ribulose-bisphosphate carboxylase, the conjugative plasmids pHG201 and pHG205 were shown to be the carriers of the genetic information for these enzymes. A restriction map of pHG201 for the enzymes AsnI, SpeI, XbaI is presented.
\end{abstract}

\section{Introduction}

The Gram-positive bacterium Nocardia opaca $1 \mathrm{~b}$ is a strict aerobe able to grow lithoautotrophically on hydrogen and carbon dioxide and heterotrophically on organic substrates such as fructose, gluconate or hydrocarbons. This bacterium provided the first system for the conjugational transfer of the genetic information for hydrogen-autotrophic growth (Aut character) to nonautotrophic mutants or species of the genus Rhodococcus (Reh \& Schlegel, 1975). The lack of transfer of auxotrophic markers and the instability of the Aut character in the donor wild-type strain and in transconjugants indicated the location of the genes responsible for the Aut character on a plasmid (Reh \& Schlegel, 1981). Enzyme studies confirmed that the genetic information for hydrogen-autotrophic growth is transferred en bloc from N. opaca to Aut ${ }^{-}$mutants of the same strain or to Rhodococcus erythropolis (Ecker et al., 1986). Three cccDNA plasmids were detected in N. opaca; however, these plasmids were detected in the wild-type Aut ${ }^{+}$donor as well as in its Aut $^{-}$variants (Reh, 1981). Further studies on the plasmids of the original strain of $N$. opaca MR11 and a newly isolated wild-type strain MR22 revealed that at least one of the plasmids of each strain

Abbreviations: ccc, covalently closed circular; CHEFE, contourclamped homogeneous-field electrophoresis; Rubisco, ribulosebisphosphate carboxylase. carried the genetic information for thallium resistance but not that for the Aut character. Even plasmid-free Aut $^{+}$strains turned out to be able to function as donors of the Aut ${ }^{+}$character (Sensfuss et al., 1986). Thus the Aut character had to be supposed to be chromosomally located as a special, frequently transferable element or as an extrachromosomal element present in a special form.

The present study was aimed at the detection of a DNA element which conferred upon transconjugants the ability to grow autotrophically with hydrogen. The study took advantage of pulsed-field electrophoresis techniques combined with a new method of DNA preparation and resulted in the detection of linear plasmids in both wild-type strains and autotrophic transconjugants of $N$. opaca.

\section{Methods}

Bacterial strains and growth conditions. Sources and references of the bacterial strains used are listed in Table 1. Strains of Nocardia opaca were grown heterotrophically as described previously (Sensfuss $e t$ al., 1986). For isolating autotrophic transconjugants an agar mating procedure was used (Reh \& Schlegel, 1981).

Preparation of cccDNA. cccDNA was prepared by an alkaline lysis procedure as described by Sensfuss et al. (1986).

Preparation of DNA for detection of linear megaplasmids. Cultures of $N$. opaca were grown and treated with sucrose and glycine as described by Sensfuss et al. (1986). After harvesting, the pellet was resuspended in $15 \mu \mathrm{I}$ EET (0.1 M-EDTA; 10 mM-EGTA; 10 mM-Tris; pH 8.0) per mg 
Table 1. Nocardia opaca strains and their plasmids

\begin{tabular}{|c|c|c|c|c|c|}
\hline \multirow[b]{2}{*}{ Strain } & \multirow[b]{2}{*}{$\begin{array}{l}\text { Relevant } \\
\text { phenotype* }\end{array}$} & \multicolumn{2}{|c|}{ Plasmids (sizes in $\mathrm{kb}$ ) } & \multirow[b]{2}{*}{ Parent strain(s) } & \multirow[b]{2}{*}{$\begin{array}{l}\text { Source or } \\
\text { reference }\end{array}$} \\
\hline & & $\begin{array}{l}\text { Form of pl } \\
\text { cec }\end{array}$ & $\begin{array}{l}\text { mid DNA: } \\
\text { linear }\end{array}$ & & \\
\hline MR11 & Aut $^{+}$ & $\begin{array}{l}\text { pHG31-a (140) } \\
\text { pHG31-b (17) }\end{array}$ & $\begin{array}{l}\text { pHG201 (270) } \\
\text { pHG202 (400) } \\
\text { pHG203 (420) }\end{array}$ & Wild-type & $\begin{array}{l}\text { DSM 427; } \\
\text { Aggag \& Schlegel } \\
\text { (1973) }\end{array}$ \\
\hline MR22 & Aut $^{+}$ & pHG33 (110) & $\begin{array}{l}\text { pHG204 (180) } \\
\text { pHG205 (280) } \\
\text { pHG206 (510) }\end{array}$ & Wild-type & $\begin{array}{l}\text { DSM 3346; } \\
\text { Sensfuss et al. } \\
(1986)\end{array}$ \\
\hline MR222 & Aut $^{-}$ & & pHG206 & MR22 & $\begin{array}{l}\text { Sensfuss } e t \text { al. } \\
\text { (1986) }\end{array}$ \\
\hline MR2226 & Aut $^{-}$Str $^{r}$ & & & MR222 & $\begin{array}{l}\text { Sensfuss et al. } \\
\text { (1986) }\end{array}$ \\
\hline MR2246 & Aut $^{+}$Str $^{\mathrm{r}}$ & & pHG201 & MR11 × MR2226 & $\begin{array}{l}\text { Sensfuss et al. } \\
\text { (1986) }\end{array}$ \\
\hline MR2247 & $\mathrm{Aut}^{+} \mathrm{Str}^{\mathrm{r}}$ & pHG31-a & pHG201 & MR11 × MR2226 & $\begin{array}{l}\text { Sensfuss } \text { et al. } \\
\text { (1986) }\end{array}$ \\
\hline MR2248 & Aut $^{-}$Str $^{r}$ & pHG31-a & & MR11 $\times$ MR2226 & $\begin{array}{l}\text { Sensfuss et al. } \\
\text { (1986) }\end{array}$ \\
\hline MR2252 & Aut $^{+}$Str $^{r}$ & pHG33 & $\begin{array}{l}\text { pHG204 } \\
\text { pHG205 }\end{array}$ & MR22 $\times$ MR2226 & This study \\
\hline MR2253 & $\mathrm{Aut}^{+} \mathrm{Str}^{\mathrm{r}}$ & & pHG205 $\Delta(210)$ & MR22 $\times$ MR2226 & This study \\
\hline
\end{tabular}

*Aut, lithoautotrophic growth; Str, streptomycin.

wet weight. Embedding of cells and preparation of DNA by lysing the cells with lysozyme, SDS and proteinase $\mathrm{K}$ was performed according to McClelland et al. (1987).

Electrophoresis. For conventional electrophoresis, $1 \%$ agarose gels in TBE (89 mM-Tris; 89 mM-borate; 2 mM-EDTA; pH 8.0) were used. Electrophoresis was performed at $2.5 \mathrm{~V} \mathrm{~cm}^{-1}$ for $6 \mathrm{~h}$. Contour-clamped homogeneous-field electrophoresis (CHEFE) was carried out using the Pulsaphor system (Pharmacia LKB). For all separations, $1 \%$ agarose slab gels $(15 \times 15 \times 0.5 \mathrm{~cm})$ in $0.5 \times$ TBE were used. Buffer was kept at $7{ }^{\circ} \mathrm{C}$, and gels were run at $6 \mathrm{~V} \mathrm{~cm}^{-1}$. DNA bands were stained with ethidium bromide and visualized by means of a UV-transilluminator. Concatemers of $\lambda$ DNA ( $\lambda$ ladder) were used as high-molecular-mass DNA standard (Anand, 1986).

Isolation and manipulation of linear megaplasmid DNA. For isolation of pHG201 DNA, agarose plugs from MR2246 and MR11 were prepared as described above, with the modification that the pellet was resuspended in $1 \mu \mathrm{lEET}$ per mg wet weight. Linear plasmid DNA was obtained either by electroelution of MR2246 DNA agarose plugs or by a preparative CHEFE gel. Electroelution was performed with an apparatus (HSB-Elutor) obtained from Biometra, Göttingen, FRG. After electroelution the DNA solution was dialysed against water. If necessary the solution was concentrated by treating the dialysis bag with Sephadex G-150. For isolation of plasmid DNA from preparative gels, agarose plugs of MR 11 were loaded onto a $0.7 \%$ low-melting-point agarose gel. CHEFE was performed for $24 \mathrm{~h}$ in $0.5 \times \mathrm{TBE}$. The pulse time was steadily increased from $10 \mathrm{~s}$ at the beginning to $80 \mathrm{~s}$ during the run time. After separation the band of pHG201 was cut out and stored in $0.5 \times \mathrm{TBE}$ at $4^{\circ} \mathrm{C}$.

Restriction digestion. To $1 \mu \mathrm{g}$ dissolved plasmid DNA, $0 \cdot 1$ vol. 10 -fold concentrated appropriate restriction buffer and $10 \mathrm{U}$ of restriction endonuclease were added. Digestion was performed at $37^{\circ} \mathrm{C}$ for $3 \mathrm{~h}$. After digestion, the reaction was terminated by addition of $0.25 \mathrm{vol}$. stop solution [0.1 M-EDTA, pH 8; 40\% (w/v) sucrose; $0.15 \%(\mathrm{w} / \mathrm{v})$ bromophenol blue]. Agarose plugs containing approximately $0.5 \mu \mathrm{g}$ plasmid DNA were equilibrated twice with $200 \mu$ l of restriction buffer for $0.5 \mathrm{~h}$. Then the buffer was replaced by $30-50 \mu \mathrm{l}$ fresh restriction buffer. Plasmid DNA was digested with $10 \mathrm{U}$ of the endonuclease. After $2 \mathrm{~h}$ an additional $10 \mathrm{U}$ of endonuclease was added. After $5 \mathrm{~h}$ at $37^{\circ} \mathrm{C}$ the reaction was terminated by adding $10-20 \mu \mathrm{l}$ of stop solution.

Southern hybridization. For fragmentation of large DNA fragments, the agarose gel was incubated twice in $0.25 \mathrm{M}-\mathrm{HCl}$ for $15 \mathrm{~min}$ (Wahl et al., 1979). The DNA was then denatured with $0 \cdot 1 \mathrm{M}-\mathrm{NaOH}, 1 \cdot 5 \mathrm{M}-\mathrm{NaCl}$ for $45 \mathrm{~min}$. For neutralization, the gel was incubated for $45 \mathrm{~min}$ in $0.2 \mathrm{M}$-Tris/HCl, $2 \times$ SSC $(1 \times$ SSC: $0.15 \mathrm{M}-\mathrm{NaCl}, 15 \mathrm{~mm}$-trisodium citrate; $\mathrm{pH} 7 \cdot 5$ ). DNA was transferred to nitrocellulose filters (BA85, Schleicher and Schuell) with $10 \times$ SSC by the Southern blot procedure (Southern, 1975) and fixed by UV-irradiation (Khandjian, 1987). All hybridization reactions were performed at $42^{\circ} \mathrm{C}$ with gentle shaking in heat-sealed plastic bags. Prehybridization was carried out for $2.5 \mathrm{~h}$ with $0.1 \mathrm{ml} \mathrm{cm}^{-2}$ of a solution consisting of $45 \%(\mathrm{v} / \mathrm{v})$ deionized formamide, $5 \times$ SSC, $5 \times$ Denhardt's solution, $(1 \times$ Denhardt's solution: $0.02 \%$ bovine serum albumin, $0.02 \%$ Ficoll, $0.02 \%$ polyvinylpyrrolidone), $0.5 \%$ (w/v) SDS, $20 \mathrm{mM} \mathrm{NaH}_{2} \mathrm{PO}_{4}$, and $250 \mu \mathrm{g}$ sonicated salmon testes DNA $\mathrm{ml}^{-1}$. After prehybridization, the buffer was replaced by hybridization buffer, containing the same ingredients plus biotinylated probe $\left(100 \mathrm{ng} \mathrm{ml}^{-1}\right)$, denatured by boiling. Hybridization probes were labelled with biotin-16-dUTP by using a nick-translation kit as specified by the manufacturer (Gibco-BRL). The filter was hybridized at $42^{\circ} \mathrm{C}$ for $16-18 \mathrm{~h}$. Washing of the filter and detection of biotinylated probes were performed as described by Chan et al. (1985).

Source of DNA probes. Detection of soluble hydrogenase structural genes of $N$. opaca was performed with a cloned $7.8 \mathrm{~kb} \mathrm{Bg} / \mathrm{II}$ fragment from MR11 DNA. The fragment was cloned into the cloning vector $\lambda L 47$ and was shown to carry the soluble hydrogenase structural genes 
by heterologous hybridization with an appropriate DNA probe from Alcaligenes eutrophus H16 (U. Seitzer \& M. Reh, unpublished results). Plasmid pCH139 served as source for this probe (A. Tran-Betcke, U. Warnecke, C. Böcker, C. Zaborosch \& B. Friedrich, unpublished). As the probe for the structural gene of the large subunits of ribulosebisphosphate carboxylase (Rubisco) a cloned $5 \cdot 1 \mathrm{~kb}$ EcoRI fragment from MR11 DNA was used. This fragment showed homology to the structural gene of Rubisco from Rhodospirillum rubrum (C. Schlüter \& M. Reh, unpublished results) which is localized on a $1.3 \mathrm{~kb}$ AvaII/BgIII fragment of pRR2119 (Nargang et al., 1984).

Fragment DNA was prepared from agarose gels using the Geneclean kit according to the instructions of the manufacturer (Bio 101 Inc., San Diego, USA)

\section{Results}

The two hydrogen-autotrophic wild-type strains MR11 and MR22 of N. opaca, Aut ${ }^{-}$derivatives of MR22 and various $\mathrm{Aut}^{+}$transconjugants (Table 1) were examined by CHEFE for the presence of linear DNA fragments. To prevent physical shearing of the DNA the cells were embedded in low-melting-point agarose plugs and then treated with lysozyme, SDS and proteinase K. CHEFE analysis revealed various distinct bands (Fig. $1 a$ ). Strain MR11 showed three DNA elements: pHG201 (270 kb), pHG202 (400 kb) and pHG203 (420 kb). The sizes were estimated by comparison with linear standards which were concatemers of $\lambda$ DNA ( $\lambda$ ladder). Strain MR22 showed three DNA elements also; their sizes were different from those of the MR11 elements: pHG204 $(180 \mathrm{~kb}), \mathrm{pHG} 205(280 \mathrm{~kb})$ and pHG206 $(510 \mathrm{~kb})$. The Aut $^{-}$mutant MR222, derived from MR22, contained only pHG206 and the secondary mutant MR2226 contained none of the elements present in the parental cells. The $\mathrm{Aut}^{+}$transconjugant pHG2252 derived from MR2226 with MR22 as donor showed the bands of pHG204 and pHG205. Further transconjugants MR2246 and MR2247 derived from MR2226 with MR11 as donor showed bands of pHG201. Finally, the Aut $^{+}$transconjugant MR2253 showed a band of $210 \mathrm{~kb}$, most probably a defective plasmid, pHG205 $\Delta$. The thallium-resistant Aut $^{-}$transconjugant MR2248 showed no linear element. When the agarose plugs with lysed cells of MR2226 and MR2248, which did not give rise to bands on CHEFE, were treated with endonuclease the typical restriction patterns appeared. This indicates that during CHEFE analysis the chromosomal DNA remained at the origin.

The DNA elements pHG201 to pHG206 are linear extrachromosomal DNA molecules, thus linear plasmids. This conclusion is derived from the method used to release the DNA from the cells and from the electrophoretic behaviour. In DNA samples prepared by the
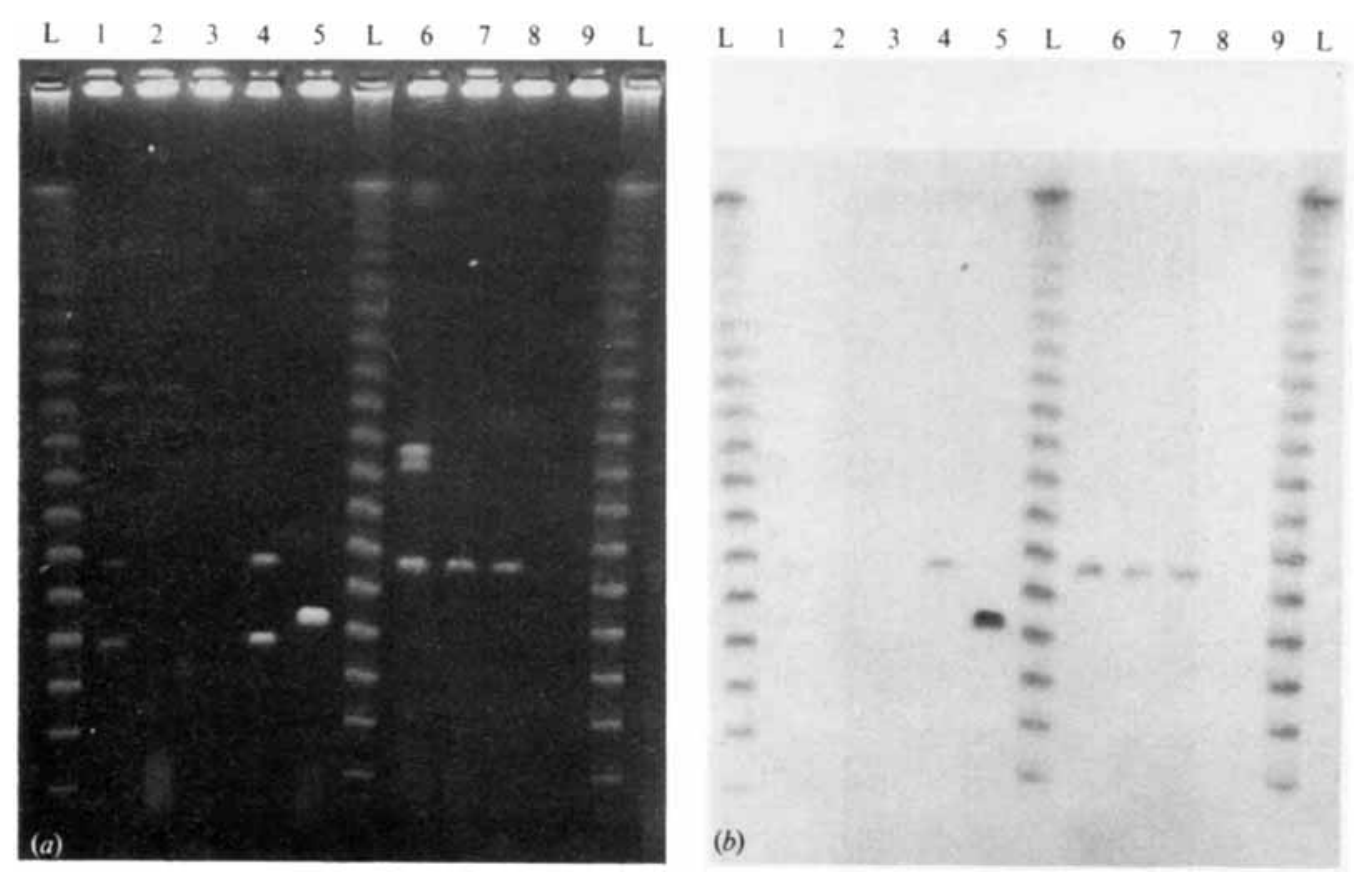

Fig. 1. Detection of linear DNA molecules in lysed cells of $N$. opaca. (a) CHEFE separation. Pulse time 10-80 s. Lanes: L, $\lambda$ ladder as molecular size standard; 1, MR22; 2, MR222; 3, MR2226; 4, MR2252; 5, MR2253; 6, MR11; 7, MR2246; 8, MR2247; 9, MR2248. (b) Localization of hydrogenase genes by Southern blot analysis. Hybridization was carried out with a biotinylated $7.8 \mathrm{~kb} B g / \mathrm{II}$ fragment of $N$. opaca MR11 and a labelled $\lambda$ DNA fragment as probe. 


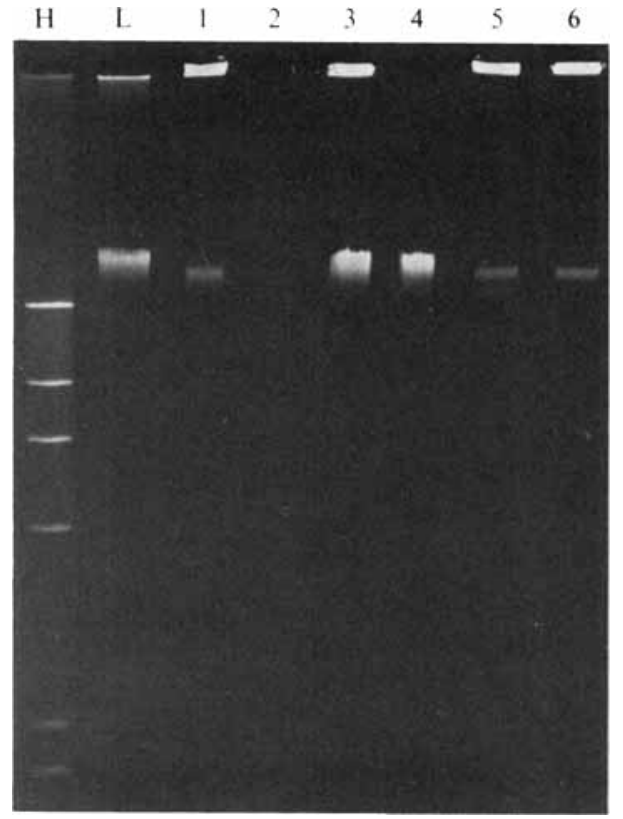

Fig. 2. Conventional agarose gel electrophoresis of $N$. opaca DNA. Lanes: H, $\lambda$ HindIII; L, $\lambda$ ladder; 1, MR22; 2, MR2226; 3, MR2252; 4, MR11; 5, MR2246; 6, MR2247. method of Marmur (1961) these linear plasmids were not detectable; this may be due to their sensitivity to shearing forces. On conventional agarose gel electrophoresis the linear plasmids formed a broad band located slightly above the largest $\lambda$ HindIII fragment (Fig. 2).

In lysates of $N$. opaca obtained by alkaline treatment, only cccDNA plasmids became visible (Sensfuss et al., 1986). Whereas the mobility of the linear plasmids was dependent on the pulse time, that of cccDNA was not affected when CHEFE was employed (Fig. 3). Figs. 3(a) and $3(b)$ show the same samples after CHEFE applying a constant pulse time of $40 \mathrm{~s}$ and $100 \mathrm{~s}$, respectively. The positions of the elements relative to the $\lambda$ ladder in the two experiments differed by about $10-20 \%$. The reason for the deviation is not known.

In all the strains mentioned, the presence of the linear plasmids pHG201 or pHG205 correlated with the Aut ${ }^{+}$ character. Southern blotting and hybridization with a DNA probe ( $7.8 \mathrm{~kb} \mathrm{BglII}$ fragment) coding for the genes of the soluble hydrogenase (hoxS) was applied to identify Aut genes on the plasmids. Strong positive signals appeared on the bands of pHG201 and pHG205 (Fig. $1 b$ ). Furthermore, the linear plasmid from MR2253, which is smaller than pHG205, gave a signal.
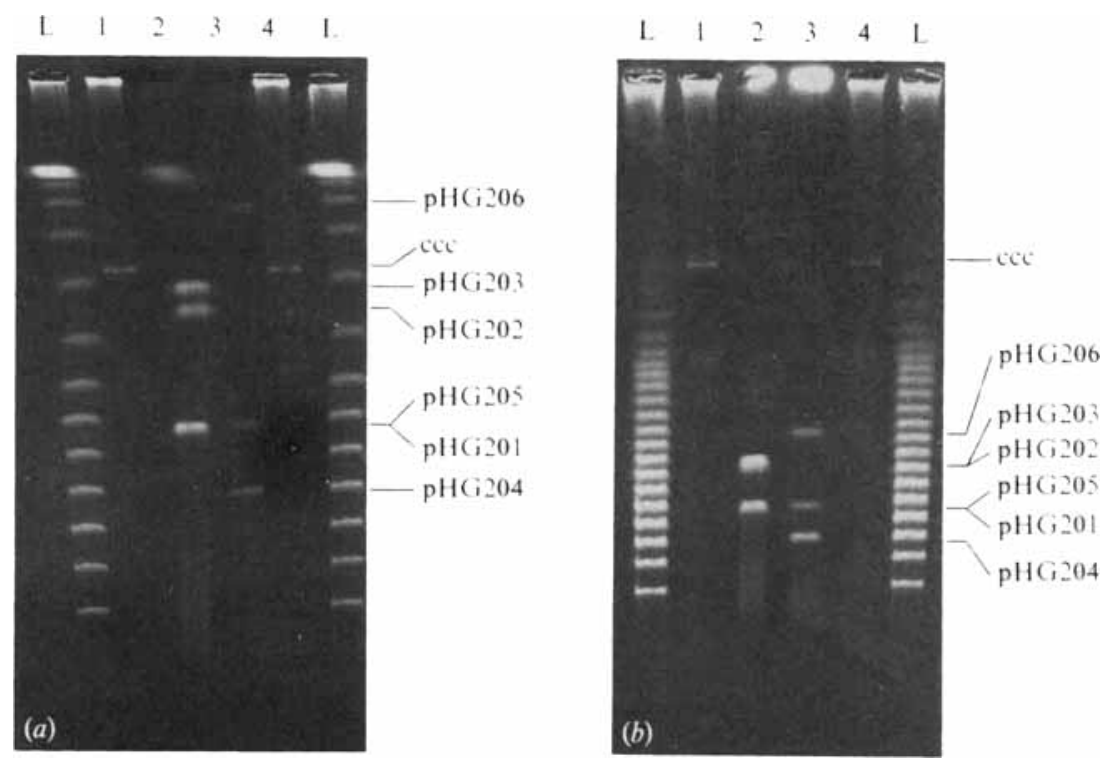

Fig. 3. CHEFE separation of isolated cccDNA in comparison to linear plasmid DNA from $N$. opaca. Lanes: $L, \lambda$ ladder; 1 and 4 , pHG31-a; 2, MR11; 3, MR22. (a) Pulse time $40 \mathrm{~s}$. (b) Pulse time $100 \mathrm{~s}$. 
Table 2. Restriction fragments of pHG201

\begin{tabular}{|c|c|c|c|c|c|c|}
\hline & \multicolumn{6}{|c|}{ Sizes of fragments $(\mathrm{kb})^{*}$ produced with: } \\
\hline & AsnI & AsnI/SpeI & SpeI & SpeI/XbaI & $X b a \mathbf{I}$ & $X b a \mathbf{I} / A s n \mathbf{I}$ \\
\hline & 190 & 100 & $200 \dagger t$ & $170 \dagger+$ & $230 \dagger \ddagger$ & 160 \\
\hline & $55 \ddagger$ & 60 & 60 & 50 & 25 & $55 \ddagger$ \\
\hline & $21 \dagger$ & $55 \ddagger$ & 16 & $16(2 \times)$ & 16 & 25 \\
\hline & $7 \cdot 2 \dagger$ & $21 \dagger$ & & 13 & $6.6 \dagger$ & 16 \\
\hline & & 16 & & $6.6 \dagger$ & & $5 \cdot 8 \dagger$ \\
\hline & & $7 \cdot 2 \dagger$ & & & & $5 \cdot 2 \dagger$ \\
\hline & & & & & & $1.4 \dagger$ \\
\hline Total: & 273 & 259 & 276 & 272 & 278 & 268 \\
\hline
\end{tabular}

* Fragment sizes are indicated in kilobase pairs as determined by CHEFE.

$\dagger$ Fragments hybridizing to the $7.8 \mathrm{~kb}$ BgIII (hydrogenase) probe.

$\ddagger$ Fragments hybridizing to the $5.1 \mathrm{~kb}$ EcoRI (Rubisco) probe.

To determine the restriction pattern, the linear plasmid pHG201 was prepared by electroelution of agarose plugs containing treated cells of MR2246. This strain contains only plasmid pHG201. The prepared plasmid DNA was subjected to restriction analysis using $X b a \mathrm{I}, A s n \mathrm{I}$ and SpeI as cleavage enzymes. These endonucleases recognize rarely cutting sites in GC-rich DNA (McClelland et al., 1987). As during electroelution of cells embedded in agarose plugs a few chromosomal DNA fragments were co-eluted, the restriction pattern showed a faint background. This artefact was finally avoided when plasmid DNA was isolated by preparative CHEFE in low-melting-point agarose gels and was digested in situ. The fragments and their sizes are listed in Table 2.

Table 2 also presents the results of hybridization experiments using DNA probes for the detection of the gene of the large subunits of Rubisco $(c f x L)$ which had been cloned as a $5.1 \mathrm{~kb} E c o \mathrm{RI}$ fragment from $N$. opaca. The $7.8 \mathrm{~kb} B g / \mathrm{II}$ fragment was again used to detect the genes for soluble hydrogenase. The results compiled in Table 2 led to the restriction map of plasmid pHG201 as shown in Fig. 4. Plasmid pHG201 is a linear molecule of $270 \mathrm{~kb}$ with defined ends. The genes for soluble

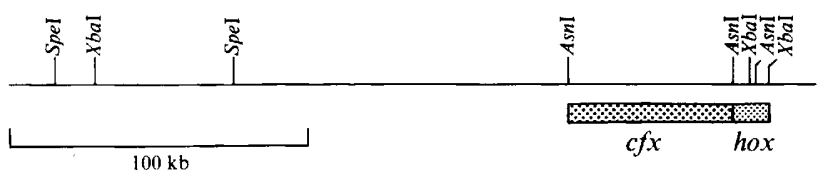

Fig. 4. Restriction map of pHG201. hox, fragments containing the hydrogenase structural genes; $c f x$, fragment containing the gene of the large subunit of Rubisco. hydrogenase were located on the $7.2 \mathrm{~kb}$ AsnI and the 6.6 $\mathrm{kb} X b a \mathrm{I}$ fragments. The gene of the large subunits of Rubisco was located on the closely adjacent $55 \mathrm{~kb} A s n \mathrm{I}$ fragment.

In order to distinguish between the Aut plasmids pHG201 and pHG205, pHG205 was also examined by restriction enzyme analysis. The restriction patterns of isolated pHG205 DNA treated with SpeI and AsnI showed some similarity to those of pHG201. The number of fragments was the same; however, the sizes of the corresponding fragments were significantly different (data not shown). Thus, pHG201 and pHG205 are not identical.

\section{Discussion}

A relationship between the Aut character of $N$. opaca and its conjugative cccDNA plasmids was excluded by a previous study (Sensfuss et al., 1986). Therefore, two possible locations of the Aut element were taken into consideration: (1) on a mobile DNA fragment integrated into the chromosome, and (2) on an extrachromosomal DNA molecule which was so far not detectable. For both possible cases the new pulsed-field gel electrophoresis techniques devised to separate large linear DNA fragments lent themselves for further studies. The integration of a large fragment would have been detected by the cleavage of the bacterial chromosomal DNA into only a few fragments and by the comparison of an $\mathrm{Aut}^{+}$ and an Aut $^{-}$strain. The differences of the restriction patterns would have provided information on the presence as well as the size of such a large element. In the present study the use of a pulsed-field electrophoresis technique resulted in the discovery of three linear 
megaplasmids in each of the two wild-type strains of $N$. opaca studied. This success is also due to the application of an alternative method for preparation of DNA in agarose plugs containing the bacterial cells. For unknown reasons this method was found not to be suited to detecting the cccDNA plasmids of $N$. opaca.

Only one among the three linear plasmids of each wildtype strain contained genetic information for the key enzymes of hydrogen autotrophy, as detected by means of Southern hybridization using a hoxS and a $c f x L$ DNA probe. The other four linear megaplasmids so far remain cryptic; efforts are being made to assign functions to them. The amount of DNA which is present in both wild-type strains of $N$. opaca in the form of extrachromosomal elements, i.e. circular and linear plasmids, is notable: about $1100 \mathrm{~kb}$ in MR22 and $1250 \mathrm{~kb}$ in MR11. These values correspond to $23 \%$ and $27 \%$, respectively, of the E. coli genome. The detection of a mutant (MR2226) which lacks these extrachromosomal elements indicates the absence of genetic information for essential metabolic properties.

The presence of linear plasmids as extrachromosomal carriers of genetic information in micro-organisms is not unusual. Within the genus Streptomyces several linear plasmids have been described. Linear plasmids designated pSLA1 and pSLA2 (17 kb each), were first discovered in Streptomyces rochei (Hayakawa et al., 1979). In $S$. azureus, plasmid pSA1 $(9 \mathrm{~kb})$ and the closely related pSA2 were found to be linear plasmids (Ogata et al., 1983). In S. clavuligerus, plasmid pSCL (12 kb) (Keen et al., 1988) was found, and in $S$. rimosus, pSRM (42 kb) (Chardon-Loriaux et al., 1986). Outside this genus, in Borrelia hermsii and B. burgdorferi linear plasmids of 28 $\mathrm{kb}$ and $49 \mathrm{~kb}$, respectively, were detected (Plasterk et al., 1985; Barbour \& Garon, 1987). Thiobacillus versutus contains the linear plasmid pTAV2 $(3.7 \mathrm{~kb})$ (Włodarczyk $\&$ Nowicka, 1988). In addition to the relatively small linear plasmids mentioned, large ones have been found, for example, in S. coelicolor (SCP1) and in S. lasaliensis (pKSL, $520 \mathrm{~kb}$ ) (Kinashi \& Shimaji, 1987; Kinashi et al., 1987). Megaplasmid SCP1 is - like the Aut plasmids in $N$. opaca - a conjugative linear element; furthermore it can be integrated into the chromosome and can mobilize chromosomal markers (Hopwood \& Wright, 1976). The wild-type S.coelicolor A3(2) was found to contain a series of linear plasmids differing from each other by $30 \mathrm{~kb}$. These plasmids $(410-560 \mathrm{~kb})$ are derivatives of SCP1 as demonstrated by Southern hybridization. In two SCP1 ${ }^{+}$ transconjugants only one linear plasmid of $350 \mathrm{~kb}$ was detected (Kinashi et al., 1987). The linear plasmids of $N$. opaca are not of this kind. The cryptic plasmids pHG202, pHG203, pHG204 and pHG206 did not show any homology to the Aut DNA probes used. It is, therefore, improbable that these plasmids are derivatives of the Aut elements pHG201 or pHG205, respectively.
The majority of the aerobic hydrogen-oxidizing bacteria contain large circular plasmids (Gerstenberg et al., 1982). In Alcaligenes eutrophus (Andersen et al., 1981; Friedrich et al., 1981) and Pseudomonas facilis (Warrelmann \& Friedrich, 1989) the capability for autotrophic growth and the presence of megaplasmids were found to be strictly correlated. In A. eutrophus $\mathrm{H} 16$ the structural genes coding for $\mathrm{H}_{2}$-dependent autotrophic growth are located on the conjugative cccDNA megaplasmid pHGl. The expression of the genes coding for the soluble (hox $S$ ) and the membrane-bound (hoxP) hydrogenase is, however, dependent on a chromosomal gene which most probably codes for a sigma factor (Römermann et al., 1989). The organization of the genes coding for the Calvin cycle in $A$. eutrophus is worth noting insofar as one cluster of genes is located on the chromosome and a second almost identical set of $c f x$ genes is located on pHG1 adjacent to the hox genes (Klintworth et al., 1985; Kortlüke et al., 1987; Husemann et al., 1988).

The present study resulting in the detection of linear plasmids coding for $\mathrm{H}_{2}$-dependent autotrophy in $N$. opaca solves the problem posed by the detection of en bloc conjugative transfer of the Aut character at a high frequency between strains and derivatives of this bacterium (Reh \& Schlegel, 1975).

We thank Bettina Kühne for excellent technical assistance in part of this work. This investigation was supported by a grant from the Deutsche Forschungsgemeinschaft.

\section{References}

Aggag, M. \& Schlegel, H. G. (1973). Studies on a Gram-positive hydrogen bacterium, Nocardia opaca strain 1b. I. Description and physiological characterization. Archives of Microbiology 88, 299-318.

ANAND, R. (1986). Pulsed field gelelectrophoresis: a technique for fractionating large DNA molecules. Trends in Genetics 2, 278-283.

ANDERSEN, K., TAIT, R. C. \& KING, W. R. (1981). Plasmids required for utilization of molecular hydrogen by Alcaligenes eutrophus. Archives of Microbiology 129, 384-390.

Barbour, A. G. \& Garon, C. F. (1987). Linear plasmids of the bacterium Borrelia burgdorferi have covalently closed ends. Science 237, 409-411.

Chardon-Loriaux, I., Charpentier, M. \& Percheron, F. (1986). Isolation and characterization of a linear plasmid from Streptomyces rimosus. FEMS Microbiology Letters 35, 151-155.

Chan, V. T.-W., Fleming, K. A. \& MCGee, J. O'D. (1985). Detection of subpicogram quantities of specific DNA sequences on blot hybridization with biotinylated probes. Nucleic Acids Research 13, 8083-8092.

Ecker, C., ReH, M. \& Schlegel, H. G. (1986). Enzymes of the autotrophic pathway in mating partners and transconjugants of Nocardia opaca $1 \mathrm{~b}$ and Rhodococcus erythropolis. Archives of Microbiology 145, 280-286.

Friedrich, B., Hogrefe, C. \& Schlegel, H. G. (1981). Naturally occurring genetic transfer of hydrogen-oxidizing ability between strains of Alcaligenes eutrophus. Journal of Bacteriology 147, 198-205.

Gerstenberg, C., Friedrich, B. \& SCHLEGel, H. G. (1982). Physical evidence for plasmids in autotrophic especially hydrogen oxidizing bacteria. Archives of Microbiology 133, 90-96. 
Hayakawa, T., Tanaka, T., Sakaguchi, K., Otake, N. \& Yonehara, H. (1979). A linear plasmid-like DNA in Streptomyces sp. producing lankacidin group antibiotics. Journal of General and Applied Microbiology 25, 255-260.

HOPWOOD, D. A. \& WRIGHT, H. M. (1976). Interactions of the plasmid SCP1 with the chromosome of Streptomyces coelicolor A3(2). In Second International Symposium on the Genetics of Industrial Microorganisms, pp. 607-619. Edited by K. D. MacDonald. London: Academic Press.

Husemann, M., Klintworth, R., Büttcher, V., Salnikow, J., WEISSENBORN, C. \& Bowien, B. (1988). Chromosomally and plasmid-encoded gene clusters for $\mathrm{CO}_{2}$ fixation ( $c f x$-genes) in Alcaligenes eutrophus. Molecular and General Genetics 214, 112-120.

Keen, C. L., Mendelovitz, S., Cohen, G., Aharonowitz, Y. \& Roy, K. L. (1988). Isolation and characterization of a linear DNA plasmid from Streptomyces clavuligerus. Molecular and General Genetics 212 , 172-176.

Khandian, E. W. (1987). Optimized hybridization of DNA blotted and fixed to nitrocellulose and nylon membranes. Bio/Technology 5 , 165-167.

KinASHI, H. \& ShIMAJI, M. (1987). Detection of giant linear plasmids in antibiotic producing strains of Streptomyces by the OFAGE technique. Journal of Antibiotics 40, 913-916.

Kinashi, H., ShImaJi, M. \& SAKAI, A. (1987). Giant linear plasmids in Streptomyces which code for antibiotic biosynthesis genes. Nature, London 328, 454-456.

Klintworth, R., Husemann, M., Salnikow, J. \& Bowien, B. (1985). Chromosomal and plasmid location for phosphoribulokinase genes in Alcaligenes eutrophus. Journal of Bacteriology 164, 954-956.

Kortlüke, C., Hogrefe, C., EBerz, G., PüHLER, A. \& Friedrich, B. (1987). Genes of lithoautotrophic metabolism are clustered on the megaplasmid pHG1 in Alcaligenes eutrophus. Molecular and General Genetics 210, 122-128.

MARMUR, J. (1961). A procedure for the isolation of desoxyribonucleic acids from microorganisms. Journal of Molecular Biology 3, 208-218.

McClelland, M., Jones, R., Patel, Y. \& Nelson, M. (1987). Restriction endonucleases for pulsed field mapping of bacterial genomes. Nucleic Acids Research 15, 5985-6005.

NARGANG, F., McIntosh, L. \& SOMER ville, C. (1984). Nucleotide sequence of the ribulosebisphosphate carboxylase gene from
Rhodospirillum rubrum. Molecular and General Genetics 193, 220-224.

Ogata, S., Koyama, Y., Sakaki, Y. \& Hayashida, S. (1983). Isolation of a linear DNA associated with pock formation in Streptomyces azureus. Agricultural and Biological Chemistry 47, 2127-2129.

Plasterk, R. H. A., Simon, M. I. \& Barbour, A. G. (1985). Transposition of structural genes to an expression sequence on a linear plasmid causes antigenic variation in the bacterium Borrelia hermsii. Nature, London 318, 257-263.

REH, M. (1981). Chemolithoautotrophy as an autonomous and transferable property of Nocardia opaca $1 \mathrm{~b}$. Zentralblatt für Bakteriologie, Mikrobiologie und Hygiene (Abteilung 1, Supplement) 11, 577583.

REH, M. \& SCHLEgEL, H. G. (1975). Chemolithoautotrophie als eine übertragbare, autonome Eigenschaft von Nocardia opaca lb. Nachrichten der Akademie der Wissenschaften Göttingen 12, 1-10.

REH, M. \& SCHLEGEL, H. G. (1981). Hydrogen autotrophy as a transferable genetic character of Nocardia opaca 1b. Journal of General Microbiology 126, 327-336.

RömermanN, D., WarrelmanN, J., Bender, R. A. \& Friedrich, B. (1989). An rpoN-like gene of Alcaligenes eutrophus and Pseudomonas facilis controls expression of diverse metabolic pathways, including hydrogen oxidation. Journal of Bacteriology 171, 1093-1099.

SENSFUSS, C., REH, M. \& SCHLEGEL, H. G. (1986). No correlation exists between the conjugative transfer of the autotrophic character and that of plasmids in Nocardia opaca strains. Journal of General Microbiology 132, 997-1007.

SOUTHERN, E. M. (1975). Detection of specific sequences among DNA fragments separated by gel electrophoresis. Journal of Molecular Biology 98, 503-517.

WAHL, G. M., STERN, M. \& STARK, G. R. (1979). Efficient transfer of large DNA fragments from agarose gels to diazobenzyloxymethylpaper and rapid hybridization by using dextran sulfate. Proceedings of the National Academy of Sciences of the United States of America 76, 3683-3687.

WarRelmanN, J. \& Friedrich, B. (1989). Genetic transfer of lithoautotrophy mediated by a plasmid-cointegrate from Pseudomonas facilis. Archives of Microbiology 151, 359-364.

WlodarczYK, M.\& Nowicka, B. (1988). Preliminary evidence for the linear nature of Thiobacillus versutus pTAV2 plasmid. FEMS Microbiology Letters 55, 125-128. 